\title{
Zooplankton partitioning in a tropical alkaline-saline endorheic Lake Nakuru, Kenya: Spatial and temporal trends in relation to the environment
}

\author{
Elijah Oyoo-Okoth ${ }^{1,2 *}$, Mucai Muchiri ${ }^{1}$, Charles C. Ngugi ${ }^{1}$, Elizabeth W. Njenga ${ }^{3}$, \\ Veronica Ngure ${ }^{4}$, Paul S. Orina ${ }^{3,5}$, Emily C. Chemoiwa ${ }^{3}$ and Bernard K. Wanjohi ${ }^{3}$ \\ ${ }^{1}$ Department of Fisheries and Aquatic Sciences, Moi University, Eldoret, Kenya, ${ }^{2}$ Department of Aquatic Ecology and \\ Ecotoxicology, Institute of Biodiversity and Ecosystem Dynamics, University of Amsterdam, Kruislaan, The Netherlands, \\ ${ }^{3}$ Department of Biological Sciences, Moi University, ${ }^{4}$ Department of Wildlife Management, Moi University, Eldoret, \\ ${ }^{5}$ Kenya Marine and Fisheries Research Institute, Kisumu, Kenya
}

\begin{abstract}
Spatial and temporal zooplankton variations were studied for 1 year in tropical alkaline-saline Lake Nakuru to determine how they partition in the habitat, relative to environmental variables. Monthly samples were collected at 10 sampling sites, with subsurface tows, using 33.5- $\mu \mathrm{m}$ mesh plankton nets. Physicochemical parameters displayed clear seasonal variations associated with precipitation patterns. Nine species, belonging to two main zooplankton taxonomic groups (ciliates; rotifers), were identified in the samples. Brachionus dimidiatus dominated the samples, accounting for $80 \%$ of the total zooplankton abundance. Kruskall-Wallis tests indicated significant $(P<0.05)$ temporal and spatial variations among all taxonomic groups. Different zooplankton species displayed a clear succession throughout the year. The total abundance of the rotifers and ciliates peaked at sampling sites near inlets during the long rainy seasons, while those in the inshore sites displayed variable succession patterns. Spatiotemporal structure of the zooplankton assemblages, and its correlation with environmental variables, indicated each species displayed distinct niche-based partitioning. The ciliates niche was associated with increasing soluble reactive phosphorus, total phosphorus and nitrite-nitrogen $\left(\mathrm{NO}_{2}-\mathrm{N}\right)$ concentrations. Niche partitioning in rotifers was associated with nitrate-nitrogen $\left(\mathrm{NO}_{3}-\mathrm{N}\right)$, conductivity and $\mathrm{pH}$. These results indicate physical niche separation, even in a small, relatively homogenous lake among species of rotifers and ciliates, providing information from which future changes in their abundance and spatial distributions can be predicted, given continuous water quality changes.
\end{abstract}

\section{Key words}

alkaline-saline lake, ciliates, niche partitioning, rotifers, tropical limnology, zooplankton composition.

\section{INTRODUCTION}

The zooplankton have a key role in the aquatic food chain as they transfer energy from primary producers to higher trophic levels (Lee 1982; Laybourn-Parry 1992; Vanni 1999). Thus, the zooplankton heterogeneity and community structure at a range of spatial and temporal scales is an important focus in aquatic ecological research. Zooplankton distribution, community structure and its measurements have been well documented (Sameoto 1986; Herman 1992; Schneider et al. 1994;

*Corresponding author. Email: elijaoyoo2009@yahoo.com

Accepted for publication 12 September 2010.
Kann \& Wishner 1995; Pinelalloul 1995; Clark et al. 2001; Masson et al. 2004; Romare et al. 2005; Patoine et al. 2006; Dodson et al. 2009). However, there are no welldeveloped, generally accepted body of knowledge as to why zooplankton biomass and community structure varies greatly in space and time (McGowen 1989; Clark et al. 2001). This is mainly because the heterogeneity of zooplankton distribution, in terms of species abundance, composition and size structure, is often affected by a multiple complex of confounding factors involving physicochemical and biological processes, geographical location, geological, hydrological and habitat types (Vera et al. 1998; Gilabert 2001; Hoffmeyer 2004).

(c) 2011 The Authors Journal compilation @ 2011 Blackwell Publishing Asia Pty Ltd 
Saline-alkaline lakes behave more like transition areas, being equivalent to estuarine environments in the marine ecosystem because of a continuous freshwater inflow that can affect the alkalinity and salinity balance (Hammer 1986). Thus, they are some of the most productive waterbodies in the world (Talling et al. 1973). While there is a large pool of literature on zooplankton community structure, relative to physicochemical and biological processes in freshwater and marine environments, we have sparse knowledge on zooplankton dynamics relative to the environment in alkaline-saline lakes, especially in the tropical environments. Although palaeoecologists have long exploited the alkalinity shifts in aquatic communities of saline lakes (Mellack \& Kilham 1974), many factors may be at interplay, either in isolation or in combination with each other, in influencing the zooplankton structure in these extreme environments. Further, some zooplankton species have been known to prey on other zooplankton species, hence the need to explore zooplankton community structure in such environments.

Lake Nakuru in Kenya is a typical small, shallow, tropical alkaline-saline Rift Valley lake. Because of the continued urbanization of the town of Nakuru and its environs, together with continued destruction of the Njoro River watershed, over the past 50 years (http://www.nationmedia. com/eastafrican/04102004/Features/Part2.html; Baldyga et al. 2008; http://en.wikipedia.org/wiki/Mau_Forest; Morgan 2009), it is suspected intense anthropogenic impacts in the catchment is leading to massive water quality changes (SUMAWA 2004; Okoth et al. 2009; Raini 2009). The water quality changes in Lake Nakuru are distinct, being influenced by the presence of rain when most of the agricultural activities take place in the catchment. It was established earlier that the variability of water quality draining into Lake Nakuru affected the phytoplankton community structure (Okoth et al. 2009). Thus, studies on the changes in zooplankton, relative to changes in water quality, which are rare and sporadic in this lake, are needed, since the available studies date back to field expeditions several decades ago, and were aimed at establishing baseline conditions during a period when human impacts were still minimal (Milbrink 1977; Vareschi 1978, 1982; Vareschi \& Jacobs 1985; Finlay et al. 1987; Yasindi 1995). It is hypothesized that environmental factors cause changes in the zooplankton abundance that influence the overall niche partitioning in Lake Nakuru. Thus, the objective of this study is to analyse the temporal and spatial patterns of the zooplankton communities, relative to the environmental changes over a 1 -year period. The relationship between rotifer and ciliates, relative to the environment in this lake, also was investigated. The results are discussed in relation to seasonal cues in the environment and best characterized by temperature, dissolved oxygen (DO) concentration, pH, total alkalinity (TA), electrical conductivity and nutrient concentrations.

\section{MATERIALS AND METHODS Study area}

The study area (Lake Nakuru) and sampling sites are illustrated in Figure 1 . Lake Nakuru $\left(36^{\circ} 05^{\prime} \mathrm{E}, 0^{\circ} 23^{\prime} \mathrm{S}\right)$ is a small, shallow, alkaline-saline endorheic lake situated within Lake Nakuru National Park. It is approximately $160 \mathrm{~km}$ north-west of Nairobi, Kenya, at an altitude of 1759 masl. The lake has a surface area of $40-60 \mathrm{~km}^{2}$, an average depth of $1 \mathrm{~m}$ and a catchment area of about $1800 \mathrm{~km}^{2}$ (SUMAWA, 2004). The air temperature ranges between 8 and $28^{\circ} \mathrm{C}$. A bimodal rainfall pattern is normally experienced in the region. Long rains often fall during the months of March-May, while short rains occur during September-October. December-February are dry months. The monthly variations in the volume of precipitation recorded from the Lake Nakuru Meteorological Station during the study period are presented in Figure 2. The lake is known for its spectacular bird fauna, particularly the lesser flamingo (Phoeniconaias minor). Other aquatic animal communities within Lake Nakuru include greater flamingo (Phonocopterus ruber), pelican (Pelicanus onocrotalus), a copepod (Lovenula africana) and midge larva (Leptochironomous deribae). A cichlid fish (Oreochromis alcalicus grahami) was introduced in this lake. The main human activities within the lakes catchment include crop farming (mainly maize and wheat), dairy farming and horticulture.

\section{Sampling and analysis}

Sampling for determination of zooplankton species composition and abundance, as well as physicochemical parameters, was performed at monthly intervals from January to December 2005 at 10 georeferenced sampling sites. The georeferenced stations had been established during a previous Kenya Wildlife Service monitoring programme and also were the sites used in earlier expeditions by Talling and Talling (1965) and Vareschi (1978, 1982). They included inlet sites, which were closer to the discharge point of the incoming rivers and offshore areas, which were further away from the point of discharge by the river inlets (Fig. 1).

Zooplankton samples were collected at the water surface $(0 \mathrm{~m})$, using subsurface tows with $33.5-\mu \mathrm{m}$ nets (diameter of $0.5 \mathrm{~m}$ ) fitted with a Hydro-Bios flow meter fixed in the mouth (volume-filtered average of $62 \mathrm{~m}^{3}$ ). 


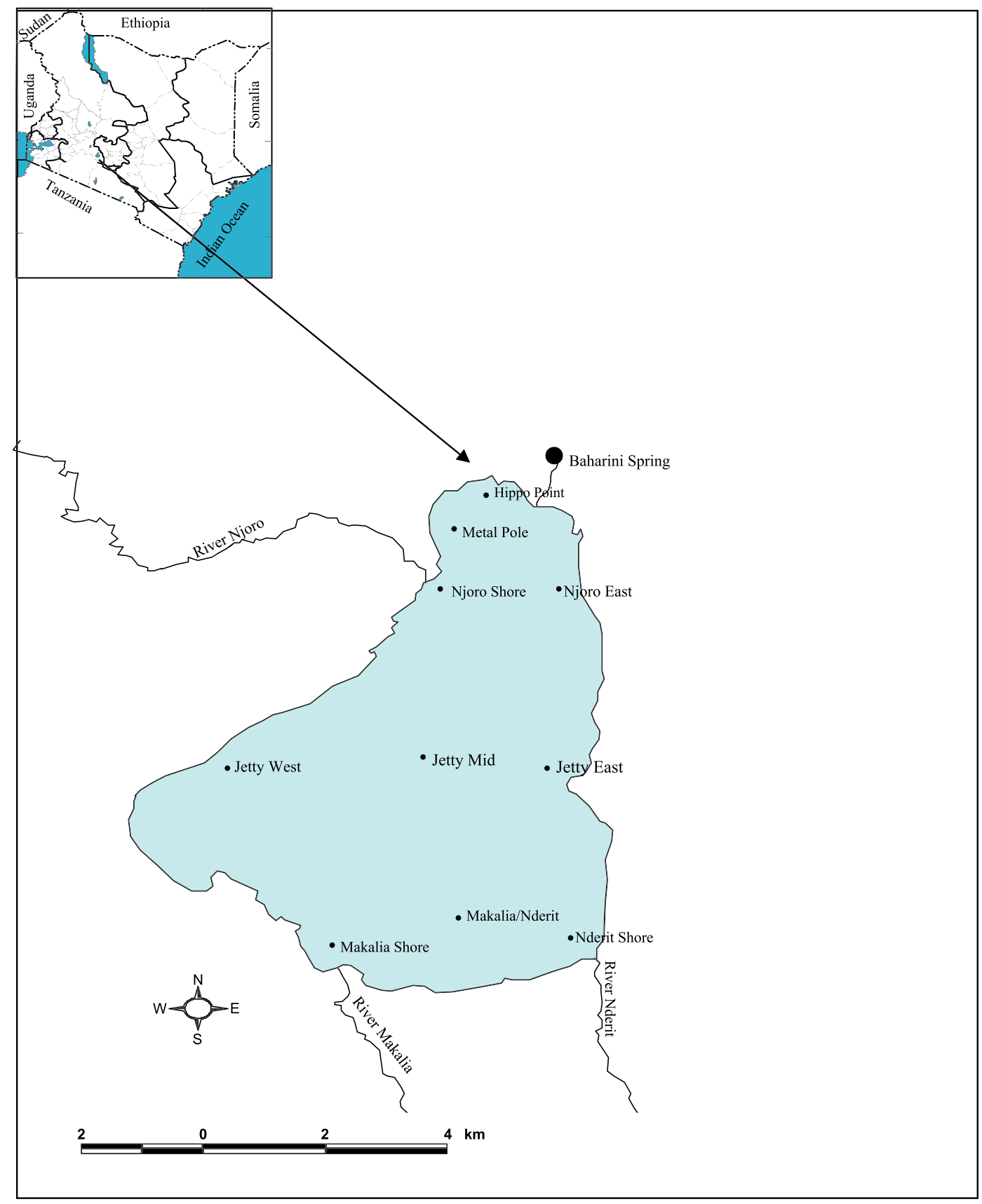

Fig. 1. Map of Kenya, showing location of Lake Nakuru and sampling sites.

The zooplankton collections were fixed in $4 \%$ neutralized formalin. Zooplankton were identified in the laboratory to the lowest taxonomic units possible. The keys of Finlay et al. (1987), Curds (1982), Curds et al. (1983), Small and Lynn (1985) and Jersabek et al. (2003) were used for zooplankton identification. Counting was made from subsamples taken with a teat pipette and placed in a $1 \mathrm{~mL}$ ( $l=50, w=20, h=1 \mathrm{~mm})$ Sedgwick-Rafter counting cell. Identification and counting were made under an optical microscope $(\times 400)$ by scanning at least 10 randomly selected longitudinal transects per cell. At least three chambers per sample were analysed. Zooplankton abundance was expressed as number of individuals per $\mathrm{m}^{3}$.

DO concentration, salinity, temperature, electrical conductivity and $\mathrm{pH}$ were measured in situ at each of the sampling sites, using a calibrated JENWAY 3405 electrochemical analyzer (Barloword Scientific Ltd, Essex, UK), with independent probes for each variable. Equipment calibration was performed at the Lake Nakuru Water Quality Laboratory before sampling, using deionized 


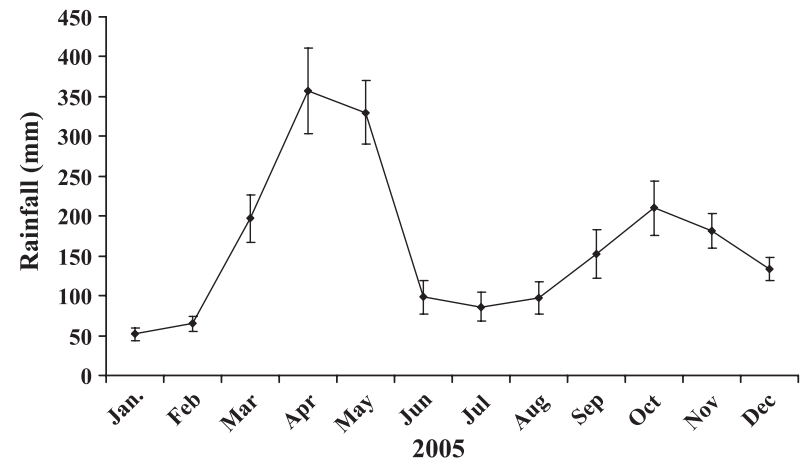

Fig. 2. Mean rainfall $( \pm$ SEM) recorded during study period (Source: Meteorological Station, Nakuru District, Kenya).

water. Water samples for nutrient determination were collected with a 3-L calibrated van Dorn sampler at the water surface $(0 \mathrm{~m})$. Portions of the water samples were used to determine nitrite-nitrogen $\left(\mathrm{NO}_{2}-\mathrm{N}\right)$ by the sulphanilamide diazotizing method, nitrate-nitrogen $\left(\mathrm{NO}_{3}-\mathrm{N}\right)$ by the diphenylamine sulphonic acid chromogene method, ammonia-nitrogen $\left(\mathrm{NH}_{3}-\mathrm{N}\right)$ by the indophenol blue method, soluble reactive phosphorus (SRP) by the standard ascorbic acid method, after filtration of the sample through a $45-\mu \mathrm{m}$ pore size membrane, and TA by the acidimetric method, with sulphuric acid as the titrant. The analyses were carried out at the Lake Nakuru water quality testing laboratory, following the standard analytical procedures detailed in APHA (1998).

\section{Data analyses}

Spatial and temporal variability of zooplankton cell density between sites, as well as among seasons, was analysed by non-parametric Kruskall-Wallis ANova (Kruskal \& Wallis 1952). Spatial variations in physicochemical parameters were analysed by one-way ANOvA, while spatiotemporal variability was analysed by two-way ANova. Tukey's HSD test was used for post hoc discrimination between significant means. The similarity/dissimilarity of sampling site, based on the zooplankton community structure, was graphically analysed by a metric multidimensional scaling ordination (MDS), which represented a matching similarities calculated in a triangular matrix of similarity coefficient computed between every pair of sampling sites. Preceding the MDS analysis, the proximity distance was calculated on the basis of Euclidean distances of the standardized data. Data were standardized, using the mean value of 1 for all the elements. The reliability and validity of the MDS solution was determined by calculating the index of fit $\left(R^{2}\right)$, which is the proportion of the variance of the optimally scaled data that can be accounted for by the MDS procedure (goodness of fit). Stress also was determined to indicate the quality of MDS, which indicated the 'badness of fit' (proportion of the variance of the optimally scaled data not accounted for by the MDS model). The relationship between species distribution and environmental factors was investigated by canonical correspondence analysis (CCA), using the CANOCO version 4.0 package (ter Braak \& Smilauer 1998). Zooplankton abundance was $\ln (x+1)$ transformed, and environmental data were standardized as appropriate before the multivariate analyses. A Monte Carlo test using 199 permutations $(P<0.05)$ was performed to test the significance of the correlations between the environmental factors and the species distribution.

\section{RESULTS \\ Environmental parameters}

Hydrological data obtained during this study are summarized in Table 1. No significant $(P>0.05)$ spatiotemporal differences in the surface water temperature were discerned among the sampling sites. All other physicochemical parameters demonstrated significant $(P<0.05)$ spatiotemporal variations. Sampling sites located near the mouth of the Inlet Rivers (except the Njoro River Shore) had higher DO concentrations than most of the inshore sites. DO concentration often exceeded 100\% saturation during the sampling. The $\mathrm{pH}$ values of inlet sites were less than those of the inshore sites, with clear differences observed during the rainy seasons. Low salinity values were measured along the freshwater inflow sites. Electrical conductivity at the southern inshore sites was higher than at other sites, although no discernable regular pattern was observed. Distinct patterns of spatial variability were observed for TA, wherein all sampling sites located near the rivers inlets had higher TA values than the other sampling sites. Although higher concentration of $\mathrm{NO}_{3}-\mathrm{N}$ was measured for the Jetty Mid and Makalia-Nderit sampling sites, no distinct variation pattern was observed in relation to sampling sites along the incoming rivers. The $\mathrm{NH}_{3}-\mathrm{N}$ and SRP concentrations were higher near the inlets of inflowing rivers.

Distinct seasonal temporal variations were discerned for all the physicochemical parameters, except for $\mathrm{NO}_{2}-\mathrm{N}$ (Fig. 3). The long rainy seasons in May/June resulted in lower water temperatures, DO concentrations, conductivity, TA and $\mathrm{pH}$. However, increased concentrations of $\mathrm{NO}_{3}-\mathrm{N}, \mathrm{NH}_{3}-\mathrm{N}$ and SRP were measured, compared to the dry season. During the rainy seasons, sampling sites closer to the inflowing river inlets had higher nutrient loads and lower DO concentrations than the inshore sites. 


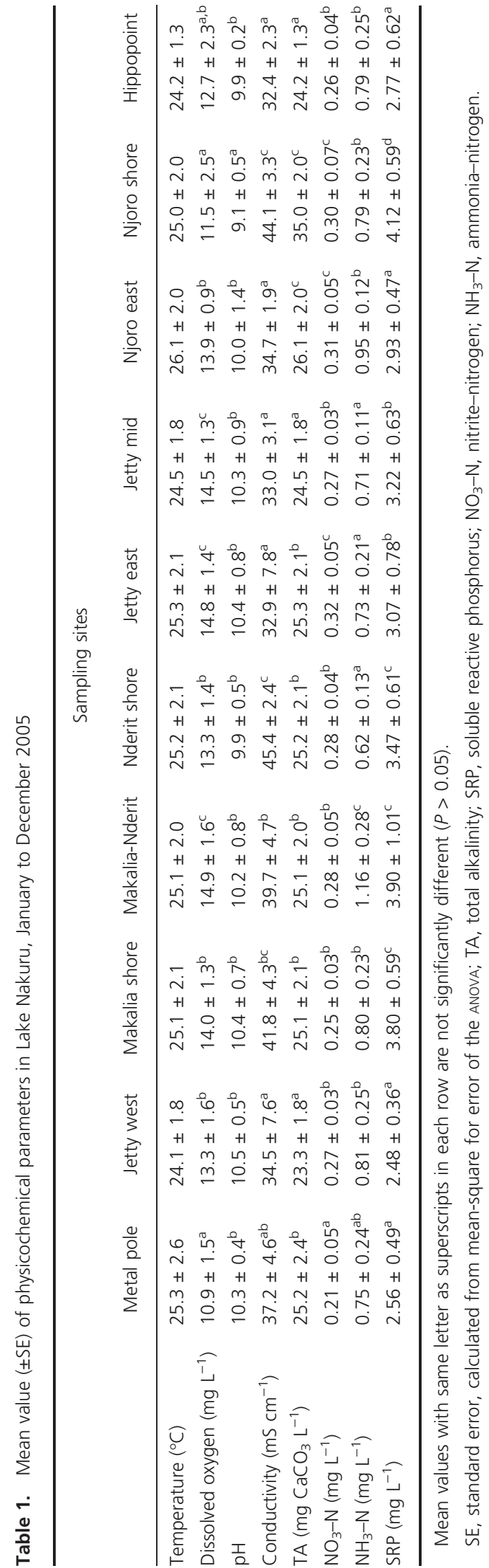

\section{Zooplankton taxonomic composition, distribution and abundance}

Two zooplankton groups, with a total of nine species, were counted in the samples during this 1-year study. Rotifers were represented by Brachionus dimidiatus, B. plicatilis, B. calyciflorus, Keratella tropica and Filinia longiseta, while ciliates were represented by Condylostoma spp., Euplotes spp., Lionatus spp., and Pleuronema spp. Brachionus dimidiatus, B. plicatilis, K. tropica and F. longiseta were present throughout the year. Lionatus spp. was the only ciliate present throughout the year (Table 2). Figure 4 illustrates the variation in the abundance of the zooplankton groups (individuals $\times 10^{3} \mathrm{~m}^{-3}$ ) during the study sampling period. Among all the zooplankton samples, $B$. dimidiatus was the more abundant, with a peak abundance $\left(>400000 \times 10^{3}\right.$ individuals $\left.\mathrm{m}^{-3}\right)$ being measured in the collected samples. Total zooplankton abundance was highly variable, with $B$. dimidiatus constituting about $80 \%$ of the zooplankton samples. Condylostoma spp. dominated among the ciliates, although the ciliates were overall lower in abundance than the rotifers.

Figure 5 illustrates the temporal distribution of the zooplankton species at each sampling site. Similar patterns of dominance by Brachionus were observed throughout the study period, with a slight abundance decrease observed during the dry season. Overall, the period between April and June 2004, which coincided with high rainfall periods, resulted in increased zooplankton abundance at the inflow sites (Fig. 5a). The inshore sites displayed different patterns of zooplankton abundance throughout the year, however, without any distinct pattern in variability of zooplankton abundance at the inshore sites. The highest rotifer abundance was recorded in Metal Pole during Septembers, while the abundance of ciliates was variable throughout the year. However, sites near the incoming Njoro River (Njoro East) exhibited higher abundances of rotifers and ciliates in April, similar to patterns in Jetty Mid (Fig. 5b).

\section{Zooplankton community structure}

Figure 6 illustrates the results of the analysis of similarities/dissimilarity of sampling sites, in terms of zooplankton structure, as determined by the non-metric MDS (NMDS) (NMDS stress factor $=0.09$ and $R^{2}=0.91$ ). The zooplankton structure was generally found to be similar at sampling sites that received freshwater inflows, except for the Njoro River (characterized by large freshwater flows). Similar zooplankton structuring was discerned for the inshore sampling sites, except for the Njoro East site. The zooplankton structure exhibited closer associations 

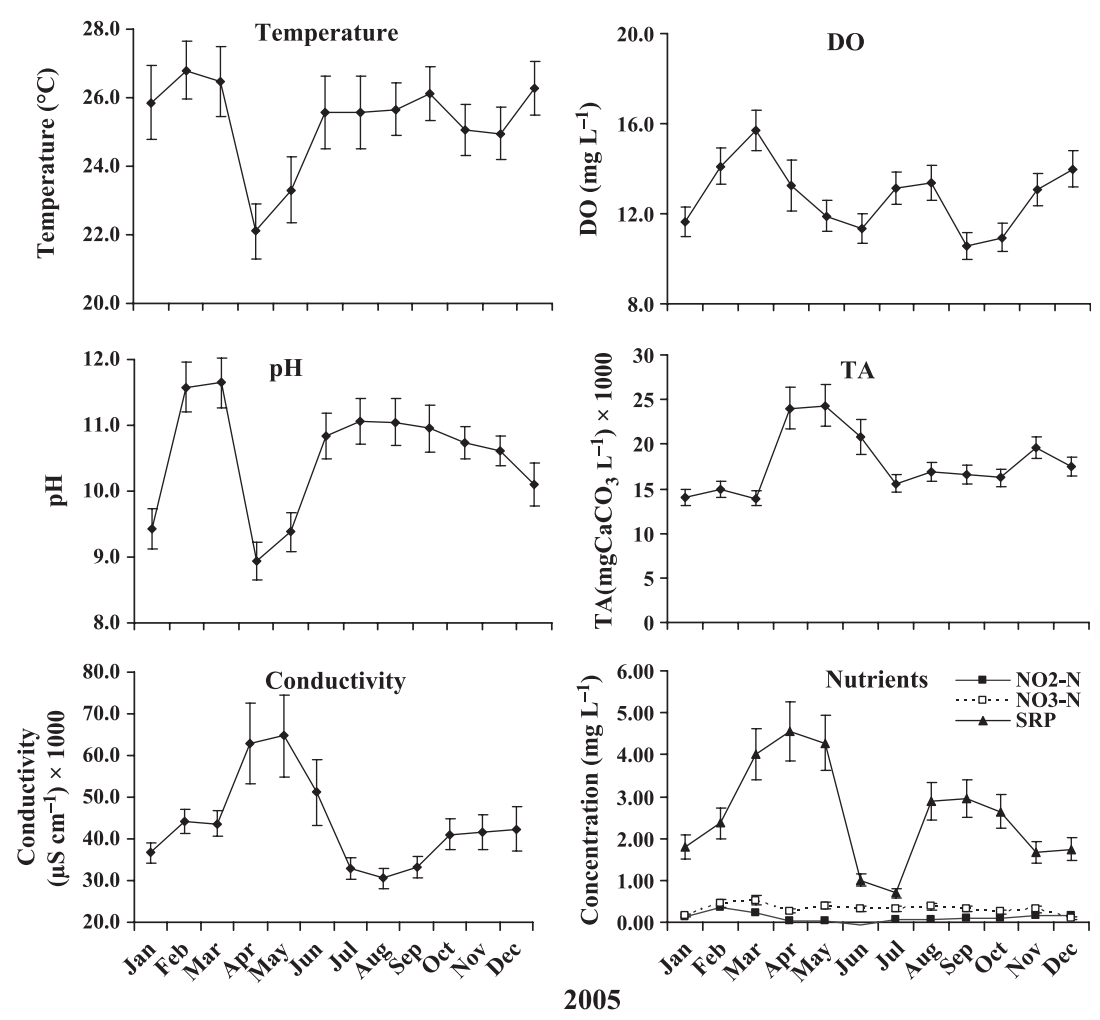

Fig. 3. Seasonal variation in physicochemical parameters for Lake Nakuru during sampling period.
Table 2. Zooplankton species observed during dry and rainy seasons in Lake Nakuru

\begin{tabular}{lllcc}
\hline Class & \multicolumn{1}{c}{ Genus } & \multicolumn{1}{c}{ Species } & $\begin{array}{c}\text { Dry } \\
\text { season }\end{array}$ & $\begin{array}{c}\text { Rainy } \\
\text { season }\end{array}$ \\
\hline Rotifera & Brachionus & Brachionus dimidiatus & + & + \\
& & B. plicatilis & + & + \\
& & B. calyciflorus & - & + \\
& Keratella & Keratella tropica & + & + \\
& Filinia & Filinia longiseta & + & + \\
& Condylostoma & Condylostoma spp. & + & - \\
& Euplotes & Euplotes spp. & + & - \\
& Lionatus & Lionatus spp. & + & + \\
& Pleuronema & Pleuronema spp & - & - \\
\hline
\end{tabular}

+ , species present; -, species absent.

at sites in the northern part of the lake (Metal Pole; Hippopoint).

The ordination results, using CCA analysis on the complete environmental and zooplankton dataset, are presented in Figure 7. Among the environmental variables, Monte Carlo permutation showed that for the zooplankton, SRP, $\mathrm{pH}$, nitrites, nitrate and conductivity were significant in explaining the ordination (in decreasing order of importance). The environmental variables considered in the CCA explained $64.8 \%$ of the total variation of the zooplankton assemblages. The first two axes alone accounted for $73.7 \%$ of the variability explained in the zooplankton abundance. It is clear that Lionatus spp. and Pleuronema spp. (top left side of the plot) are associated with increasing SRP. In addition, these two species are associated with some degree of increasing levels of total phosphorus and nitrite. However, most of the rotifers inhabited zones associated with increased nitrate, electrical conductivity and $\mathrm{pH}$ situated at the lower left side of the plot.

\section{DISCUSSION}

Sporadic efforts have been made since the 1960s to provide information aimed at improving the environmental quality of Lake Nakuru to minimize the mortality of aquatic biota (Talling \& Talling 1965; Vareschi 1978, 1982; Vareschi \& Jacobs 1985). Recent studies in alkalinesaline Lake Nakuru were undertaken to establish water quality of the lake, in relation to the mortality of lacustrine biota (Ndetei \& Muhandiki 2005) and to the spatiotemporal variation in phytoplankton (Okoth et al. 2009), because of suspicion that the nearby town of Nakuru was influencing the quality of the water draining into the lake (Odada et al. 2007). However, little information is known about zooplankton dynamics in this alkaline endorheic lake, which continue to receive more than $80 \%$ of its 
Fig. 4. Total abundance $[\log (x+1)]$ and relative abundance of rotifer (a) and ciliates (b) to total zooplankton abundance (similar scales were used for comparison of total and \% abundance of zooplankton species).

Fig. 5. (a) Monthly pattern of abundance $\left(10^{3}\right.$ individuals $\left.\mathrm{m}^{-3}\right)$ of rotifer (a) and ciliates (b) at inflow sites (different scales were used to compare rotifers and ciliates). (b) Monthly pattern of abundance (individuals $\mathrm{m}^{-3}$ ) of rotifer (a) and ciliates (b) at inshore sites (different scales were used to compare rotifers and ciliates.
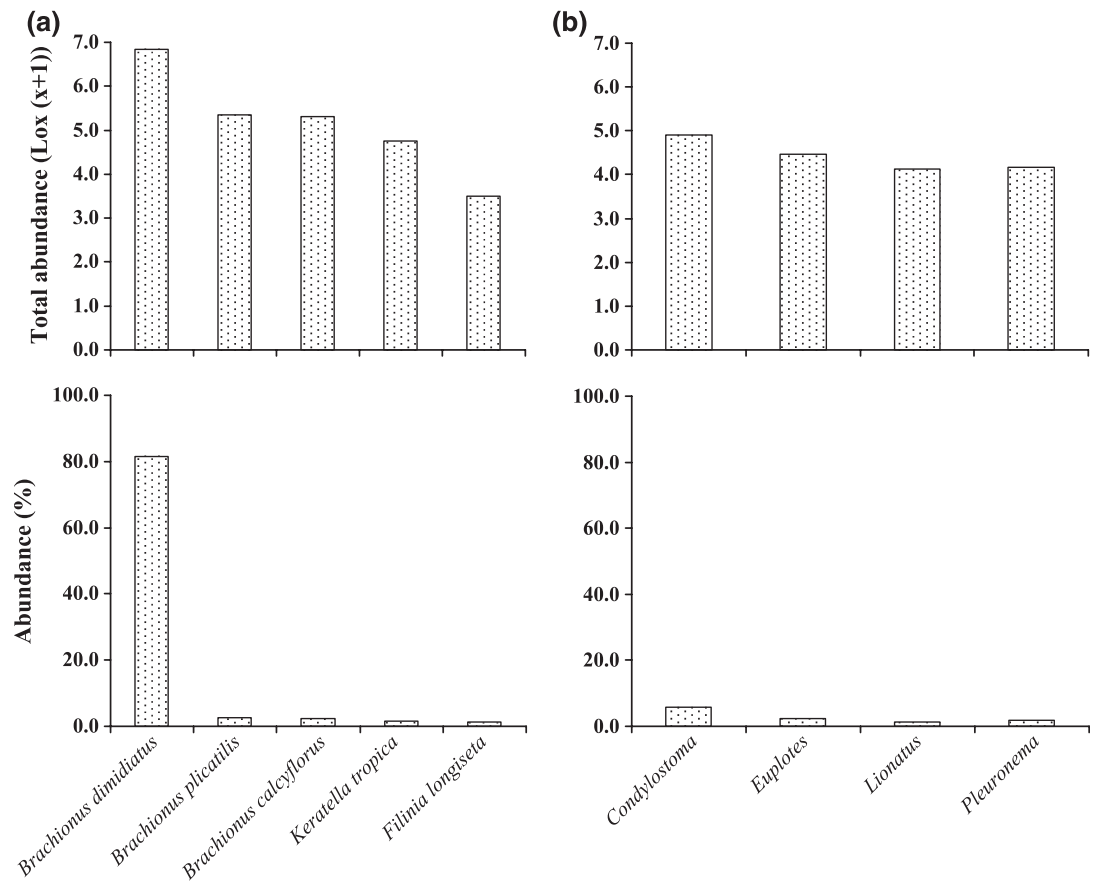

(a)

(i)
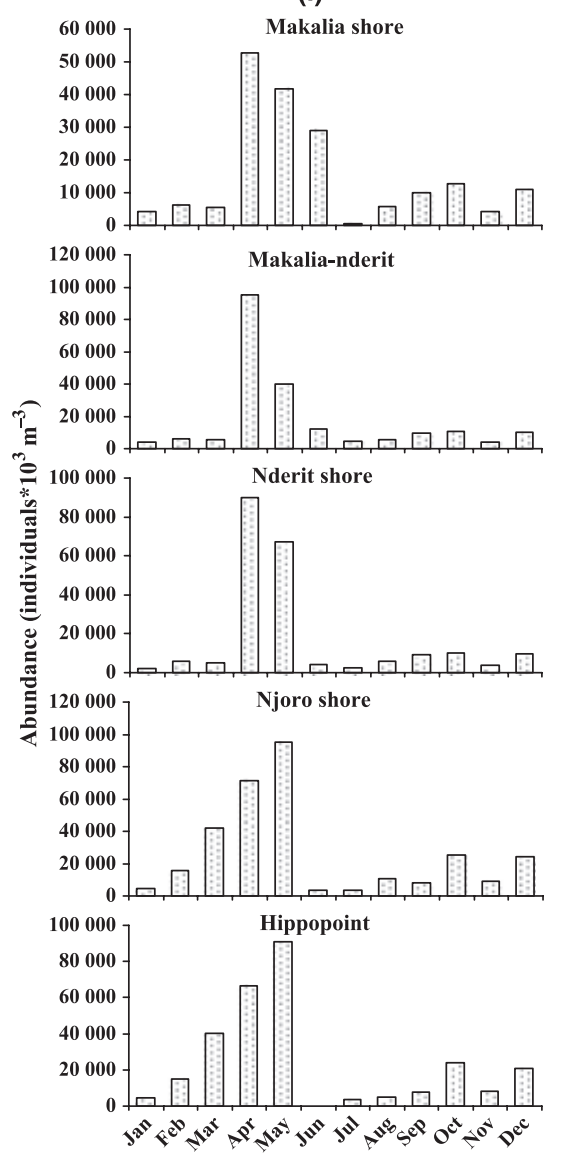

2.

2005
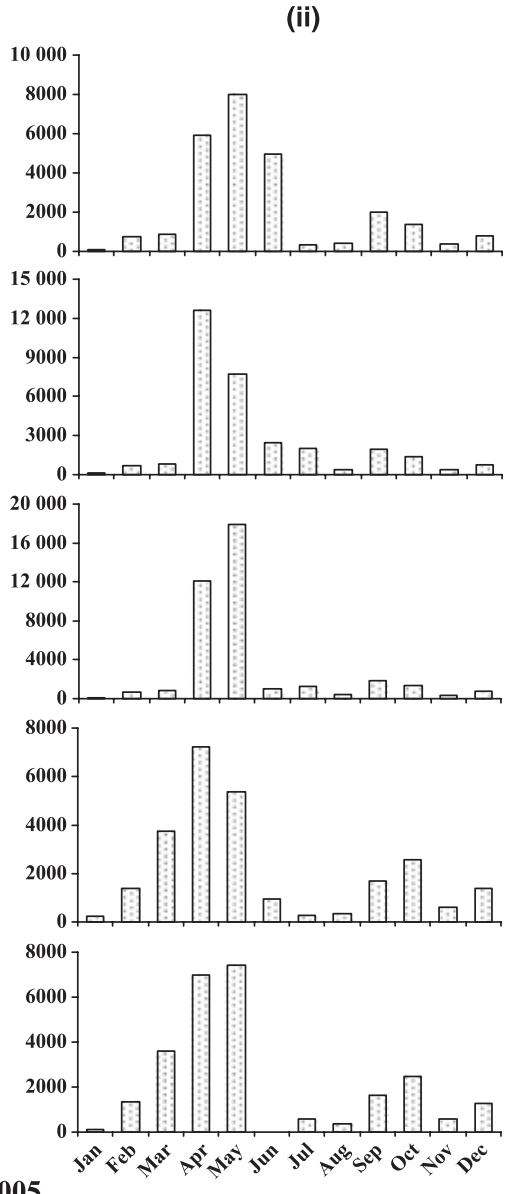

(C) 2011 The Authors Journal compilation (c) 2011 Blackwell Publishing Asia Pty Ltd 
(b)
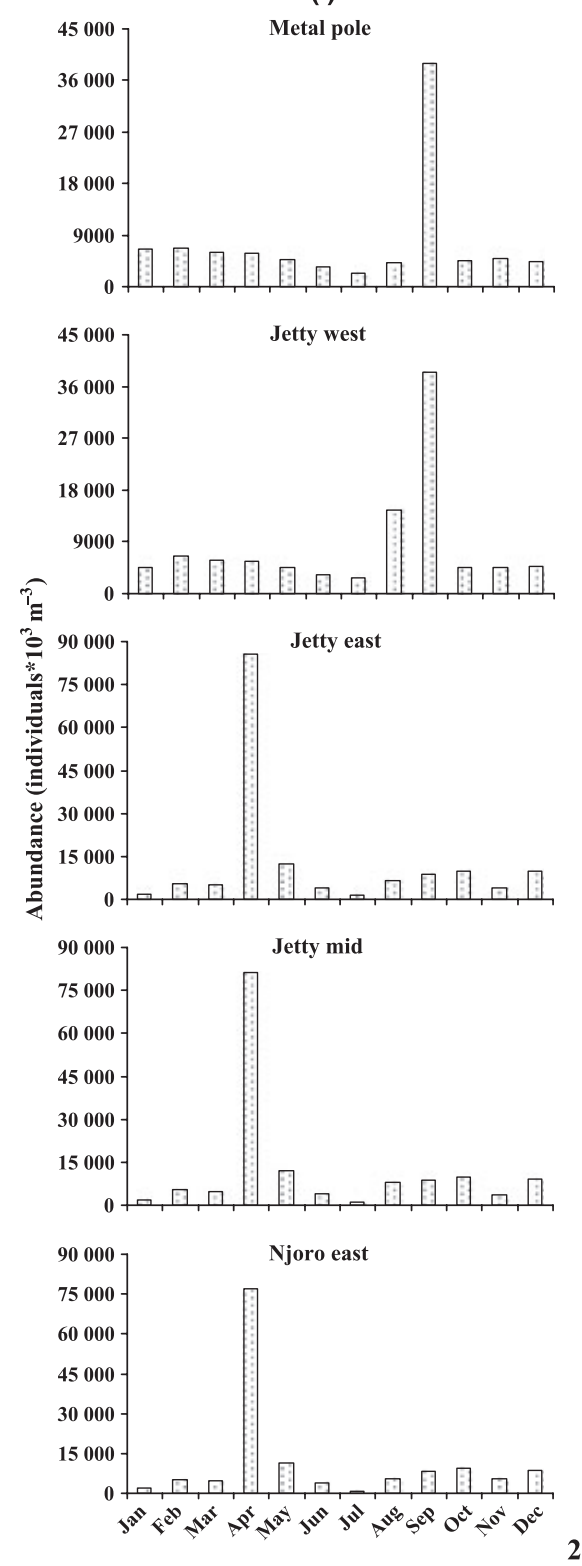

(ii)
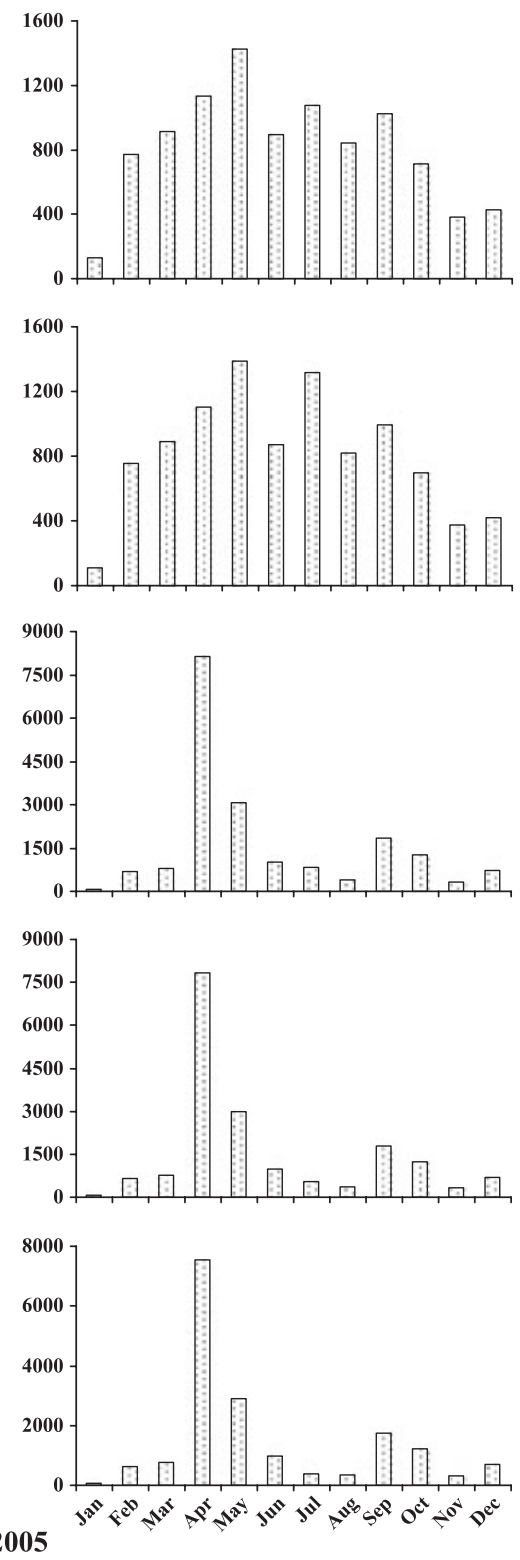

Fig. 5. (Continued)

water from the Njoro River that passes the adjacent town of Nakuru. Thus, the purpose of the present study was to examine temporal and spatial patterns in the zooplankton community, relative to the environmental gradient, to increase our knowledge about this important component of the pelagic trophic web in this alkaline-saline tropical lake.

The physicochemical environment of Lake Nakuru displayed clear seasonality associated with rainfall patterns (Figs 2,3). It must be noted that, among the three rivers draining into Lake Nakuru, only the Njoro River is permanent, contributing much of the inflowing water to the lake, while the others are dry for most parts of the year, particu- larly during the long dry seasons. As the main water inflow into Lake Nakuru, the Njoro River appeared to affect the limnological conditions of the lake. For this site, for example, the low DO concentration and $\mathrm{pH}$, coupled with high conductivity, TA and high SRP concentration, provided vital evidence that the water quality that drains into Lake Nakuru was affected at this inlet point. Low DO concentrations, coupled with high SRP concentrations, at the sampling sites situated near the Njoro River drainage were also encountered in earlier phytoplankton studies in this lake (Okoth et al. 2009), which could be attributed to microbial respiration from the sewage effluents that periodically flow into the Njoro River about $2 \mathrm{~km}$ from the 


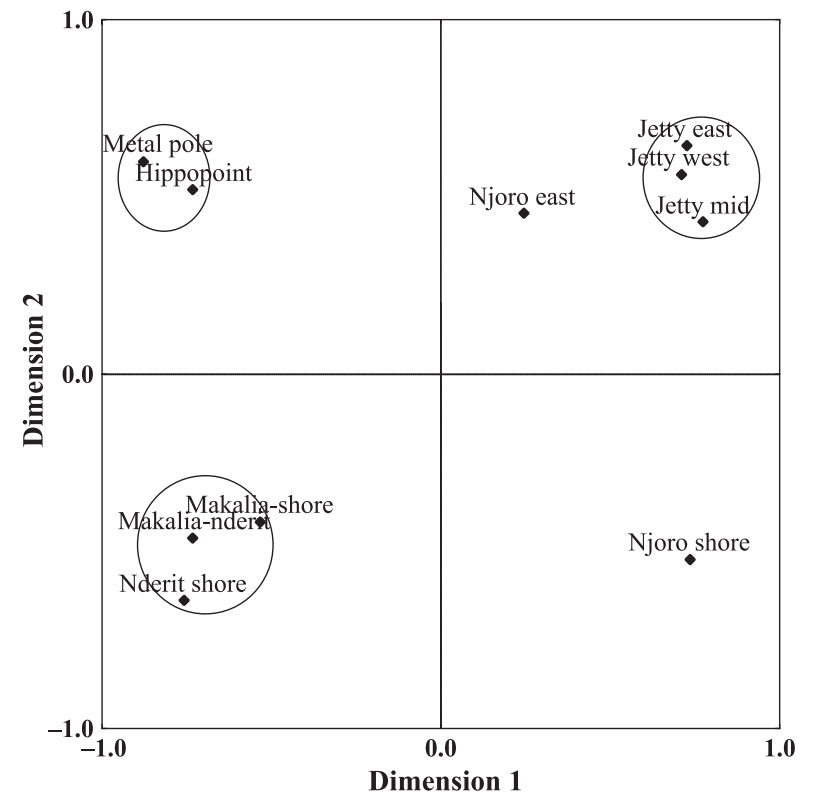

Fig. 6. Non-metric multidimensional scaling analysis showing similarity of sampling sites, based on species community structure of Lake Nakuru during study period.

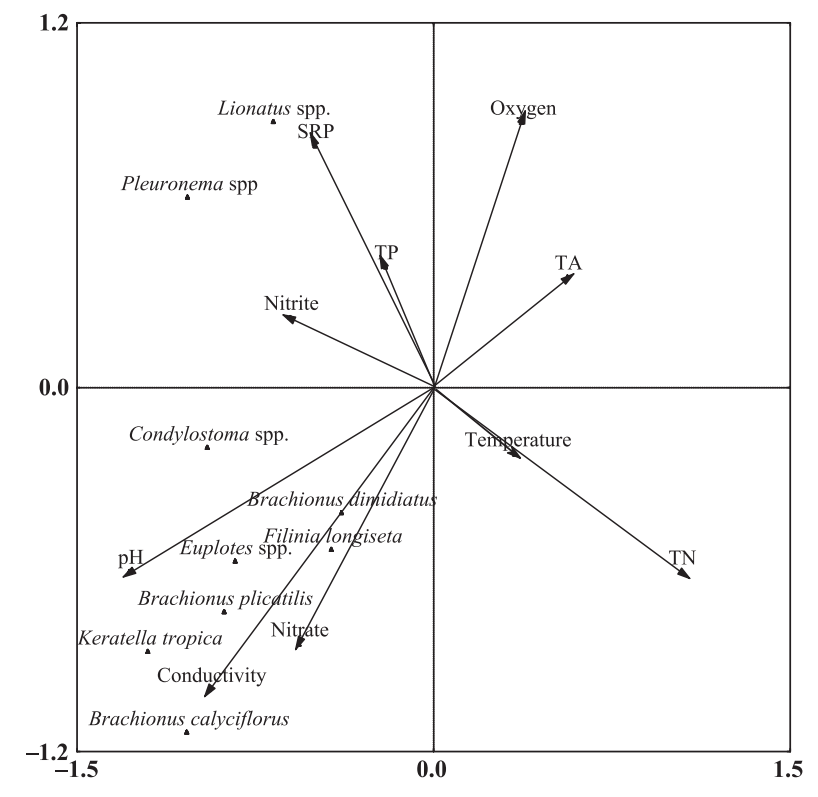

Fig. 7. Results of canonical correspondence analysis analysis on complete environmental variable vectors and species structure in Lake Nakuru during study period.

lake. The variability was high during the rainy seasons, indicating the influence of discharges and/or overland flows to the water quality parameters in the lake. Further, it also is possible that the observed differences in the physicochemical parameters between the water at the Njoro River inflow site, and other inflow sites, may be the result of anthropogenic impacts in the catchment. This is mainly because the water quality at the Njoro River inflow site was considerably outside the ranges reported in earlier studies on this lake (Talling \& Talling 1965; Vareschi 1978; Ndetei \& Muhandiki 2005). Although most limnological studies have reported that water quality changes are expected over a time scale, if the changes are extreme within a shorter time span, there are signs of water quality perturbations. The observed large variability in water quality conditions (also suggested by large spatiotemporal variations) could be associated with the degradation of the Lake Nakuru catchment (SUMAWA 2004), which has been a subject of heated debate in Kenya over the last decade (http://en.wikipedia.org/wiki/Mau_Forest; Baldyga et al. 2008; Morgan 2009; http://www.ens-newswire. com/ens/sep2009/asp; http://en.wikipedia.org/wiki/Mau_ Forest; http://kenvironews.wordpress.com/2008/07/19/ mau-forest-destruction/). This variability may be reflected in the nature of variations in the bases of the food web characterized by the zooplankton structure in the lake.

Lake Nakuru was characterized by a low species diversity and simple community structures, wherein few tolerant and adapted species attained high population densities, as previously reported for this lake (Jenkins 1957; Vareschi 1982). It is apparent that the low zooplankton species diversity is attributable to the extreme abiotic conditions prevailing in this lake, which is beyond the tolerance thresholds of many species. The zooplankton taxa encountered in Lake Nakuru during this study differed from those previously reported for this lake (Milbrink 1977; Vareschi 1982; Finlay et al. 1987; Yasindi 1995), where between 15 and 20 zooplankton species were recorded. Because the sample collection methods in this study differed from those of earlier studies, comparison of the results of this study with those of previous results must be interpreted with caution. Notwithstanding the differences in collection methods, the possibility of actual changes in the zooplankton community in the years between both studies cannot be discarded. Spatial variability is a structural character of an ecosystem. Spatial distributions allow for complex population interactions involving energy transfer, competition and niche apportionment (Brower et al. 1990). Milbrink (1977) found that the zooplankton community composition in East African lakes can change completely in relatively short time. Thus, the probable existence of important interannual shifts in the planktonic fauna of Lake Nakuru points to the need for more studies on an annual basis, as well as on longer terms.

In the current study, rotifers were identified as the dominant taxa within the zooplankton community of the

(C) 2011 The Authors Journal compilation (c) 2011 Blackwell Publishing Asia Pty Ltd 
lake at all sampling sites. There was a clear dominance by Brachionus species, which contributed over $80 \%$ to the overall zooplankton abundance. Although it has been demonstrated that the abundance of rotifers closely coincides temperature variations, because temperature has a major influence on their reproductive rate, feeding, movement and longevity (Wetzel 1983), the present study did not detect any relationships between temperature and rotifer abundance, as has been observed for some tropical lakes (Lionard et al. 2005). This could be associated with relatively high temperatures throughout the year; as such, it was not limiting for phytoplankton productivity. The low abundance of some zooplankton taxa in Lake Nakuru cannot be considered a symptom of food limitation because phytoplankton (mainly Arthrospira fusiformis) is present in abundance (Okoth et al. 2009), and although not all phytoplankton species are edible, there is sufficient biomass capable of supporting the zooplankton. Anthropogenic impacts from changes in land-use practices often affect zooplankton diversity patterns in lakes receiving water from the impacted catchments (Death 2000), often leading to decreased taxa abundance, as well as shifts to a more unevenly distributed community containing only one or two numerically dominant taxa (Jones et al. 2002). Wide ranges of land-use activities have been reported in the upper reaches of the Njoro River (Kibichii et al. 2007; Shivoga et al. 2007; Baldyga et al. 2008). These human activities can ultimately affect spatial variations and/or dominance of zooplankton species in Lake Nakuru. Higher taxa compositions and less dominance by few species, for example, have been observed in other saline-alkaline environments experiencing less human activities in their catchment areas (e.g. Lakes Magadi, Sonachi, Bogoria and Natron; Ndetei, unpubl. data 2001).

Clear seasonality in the abundance of different zooplankton taxa was observed in this study. This is evident from the increased zooplankton abundance during the rainy season, with a large influx of organic materials from the catchment. The highest zooplankton abundance was observed during periods of long rains, similar to the observed increase in phytoplankton density and biomass (Okoth et al. 2009). Thus, the abundance of zooplankton in this lake seems to be driven by rainfall patterns that bring nutrients into the lake for phytoplankton as main food items. Absence of clear seasonal patterns of zooplankton in the inshore sites could indicate that inflowing water, especially during rainy seasons, does not dictate much of the zooplankton population located away from the points of entry into the lake, perhaps because of the continuous mixing of water in the lake owing to its shal- low depth (an average of about $1 \mathrm{~m}$ ). Moreover, the monthly fluctuations of zooplankton total abundance may result from the combination of specific and contrasting population patterns. In addition, the interaction between currents induced by wind breeze and river flow can also potentially mask the seasonality of some zooplankton by introducing a superimposed variability that is reflected in the complex response of zooplankton to the biological and environmental conditions (Ribera d'Alcalà et al. 2004). It should also be noted that some taxonomic groups were only sorted to the level of genus because of the absence of specific keys to identify the zooplankton species. There may be much species-specific seasonality occurring that will be missed at this taxonomic level. However, in lakes where planktivores and high density of flamingos abound, it can be difficult to distinguish which of these changes occur as a result of predation, eutrophication, human impacts or both. This issue requires further study.

The NMDS revealed that the zooplankton structure was similar among the sampling sites that received freshwater inflows, except the Njoro River (characterized by large freshwater flows). Site-specific differences in the zooplankton community structure among the inflow sampling sites in the northern location of the lake, and differences in the Njoro River, could suggest differences in the origin of the water. The Makalia and Nderit Rivers originate in a different catchment from that of the Njoro River. The water of the Njoro River passes adjacent to the town of Nakuru and, therefore, seems to exhibit different patterns of influence on the zooplankton community structure, compared to the other inflowing rivers. The lake is normally homogenous, because diurnal winds mix its water almost on a daily basis because of its small size and shallow depth. Mellack and Kilham (1974) reported a uniform distribution of species in the lake, attesting to its homogeneity in relation to its biotic assemblages. This might suggest, therefore, that the inshore sites in the lake that do not experience any influences of large rivers (such as the Njoro River) are homogenous.

The CCA analysis revealed that the main environmental gradients were because of SRP, $\mathrm{pH}$, nitrites, nitrate and conductivity. Nutrients and dissolved ions act as minerals for the growth of phytoplankton that can be grazed by zooplankton, thereby having a pronounced spatial effect on the zooplankton composition and distribution. The $\mathrm{pH}$ and conductivity seem to provide suitable habitats for zooplankton to feed, grow and reproduce in saline ecosystems. There was very little evidence of rotifer predation on the ciliates, probably because the rotifers fed 
on the more abundant phytoplankton (Okoth et al. 2009). The most abundant fish in Lake Nakuru is the cichlid species of Oreochromis alcalicus grahamii, which is planktivorous. The food preference of this fish is phytoplankton and zooplankton, and given their opportunistic character, they can also be considered important zooplankton predators.

\section{CONCLUSION}

The results of the present study demonstrate that the extreme values of the physicochemical parameters of Lake Nakuru resulted in low species diversity, but a high abundance and dominance by one specialized species of zooplankton. It is also clear that water quality changes have impacts on the zooplankton abundance of Lake Nakuru. Moreover, there was no evidence of grazing by rotifers, suggesting that other factors could control the ciliate population. Given our inability to determine the exact control mechanism, future controlled studies are needed to provide this link. The overall findings of this study indicate there is a significant influence on the lake's biotic structure by water that originates from the catchment area via the influent river. However, it also appears that zooplankton composition, abundance and ecology of Lake Nakuru have been modified by the urbanization process of the nearby town of Nakuru, because of it close proximity to the town centre $(\approx 5 \mathrm{~km})$. Accordingly, lake management measures should focus on controlling pollutant inputs from the town. This underscores an urgent need for continuing monitoring of the lake's water quality and zooplankton populations. The effluents from the nearby town of Nakuru should also be better studied, as a means of avoiding direct pollution effects that could influence the lake's water quality and zooplankton community structure. To manage other saline-alkaline lakes, ecological approaches focusing on zooplankton community structure should be used. With such initiatives, water quality changes likely to cause adverse changes to the biotic assemblages can be discerned sufficiently early to allow corrective measures to be developed and implemented before irreparable ecological damages occur to the aquatic system.

\section{ACKNOWLEDGEMENTS}

The authors thank the Global Livestock Collaborative Research Support Program of the US-AID for its financial support through the Sustainable Management of Watershed (SUMAWA) Project that facilitated this research. Sample collection was facilitated by Robert Ndetei of Kenya Wildlife Service (KWS). David Kulecho and Peter Ngatia of the Lake Nakuru Water Quality Laboratory assisted in analysis of water quality parameters. The monthly sample collection trips were organized by Mr Akula, to whom we also are grateful.

\section{REFERENCES}

APHA (1998) Standard Methods for the Examination of Water and Wastewater, 20th edn. pp. 1124. American Public Health Association, Washington, DC.

Baldyga T. J., Miller S. N., Driese K. L. \& Gichaba C. M. (2008) Assessing land cover change in Kenya's Mau Forest region using remotely sensed data. Afr. J. Ecol. 46, 46-54.

ter Braak C. J. F. \& Smilauer P. (1998) CANOCO Reference Manual and User's Guide to Canoco for Windows, Software for Canonical Community Ordination (Version 4). pp. 352. Microcomputer Power, Ithaca, NY, USA.

Brower J. E., Zar J. H. \& von Ende C. N. (1990) Field and Laboratory Methods for General Ecology. William C. Brown Publishers, New York.

Clark D. R., Aazem K. V. \& Hays G. C. (2001) Zooplankton abundance and community structure over a $400 \mathrm{~km}$ transect in the north-east Atlantic. J. Plankton Res. 23, $365-72$.

Curds C. R. (1982) British and Other Freshwater Ciliated Protozoa. Part I. Ciliophora: Kinetofragminora. pp. 387. Cambridge University Press, Cambridge.

Curds C. R., Gates M. A. \& Roberts M. C. L. (1983) British and Other Freshwater Ciliated Protozoa. Part II: Oligohymnephora and Polyhymnephora. pp. 474. Cambridge University Press, Cambridge.

Death R. G. (2000) The effect of land use on the species area relationships in benthic stream invertebrates. Verh. Int. Ver. Theor. Angew. Limnol. 27, 2519-22.

Dodson S., Newman A. L., Will-Wolf S. et al. (2009) The relationship between zooplankton community structure and lake characteristics in temperate lakes (Northern Wisconsin, USA). J. Plankton Res. 31, 93-100.

Finlay B. J., Curds C. R., Bamforth S. S. \& Bafort J. M. (1987) Ciliated protozoa and other micro-organisms from 2 soda lakes (Lake Nakuru and Lake Simbi, Kenya). Arch. Protistenk. 133, 81-91.

Gilabert J. (2001) Seasonal plankton dynamics in a Mediterranean hypersaline coastal lagoon, the Marine Menoroplankton. J. Plankton Res. 23, 207-17.

Hammer U. T. (1986) Saline Lake Ecosystems of the World. pp. 616. Dr. W. Junk Publishers, The Hague.

Herman A. W. (1992) Design and calibration of a new optical plankton counter capable of sizing small zooplankton. Deep-Sea Res. 39, 395-415.

(c) 2011 The Authors Journal compilation @ 2011 Blackwell Publishing Asia Pty Ltd 
Hoffmeyer M. S. (2004) Decadal change in zooplankton seasonal succession in the Bahía Blanca estuary, Argentina, following introduction of two zooplankton species. J. Plankton Res. 26, 181-9.

Jenkins P. M. (1957) Reports on the Percy Sladen expedition to some Rift Valley Lakes in Kenya in 1929. Introductory account of the biological survey of five fresh and alkaline lakes. Ann. Mag. Nat. Hist. Ser. 10, 533-53.

Jersabek C. D., Segers H. \& Morris P. J. (2003) An illustrated online catalog of the Rotifera in the Academy of Natural Sciences of Philadelphia (version 1.0). Available from URL: http://rotifer.acnatsci.org/rotifer.php. Accessed 8 April 2003.

Jones C., Palmer R. M., Matkaluk S. \& Walters M. (2002) Watershed Health Monitoring: Emerging Technologies. CRC Press, Boca Raton, FL.

Kann L. M. \& Wishner K. (1995) Spatial and temporal patterns of zooplankton on baleen whale feeding grounds in the southern Gulf of Maine. J. Plankton Res. 17, 235-62.

Kibichii S., Shivoga W. A., Muchiri M. \& Miller S. N. (2007) Macroinvertebrate assemblages along a landuse gradient in the upper River Njoro watershed of Lake Nakuru drainage basin, Kenya. Lake Reserv. Manage. 12, 107-17.

Kruskal W. H. \& Wallis W. A. (1952) Use of ranks in one criterion analysis of variance. J. Am. Stat. Assoc. 47, 421-583.

Laybourn-Parry J. (1992) Protozoan Plankton Ecology. pp. 231. Edmundsbury Press, Chapman and Hall, Britain.

Lee J. L. (1982) Physical, chemical and biological quality related food web interactions as factors realized niches of micro-zooplankton. Ann. Inst. Oceanogr. 58, 19-30.

Lionard M., Azémar F., Boulêtreau S. et al. (2005) Grazing by meso- and microzooplankton on phytoplankton in the upper reaches of the Schelde estuary (Begium/ The Netherlands). Est. Coast. Shelf Sci. 64, 764-74.

Masson S., Pinelalloul B. \& Dutilleul P. (2004) Spatial heterogeneity of zooplankton biomass and size structure in southern Québec lakes: Variation among lakes and within lake among epi-, meta and hypolimnion strata. J. Plankton Res. 26, 1441-58.

McGowen J. A. (1989) Pelagic ecology and Pacific climate. In: Aspects of Climatic Variability in the Pacific and Western Americas (ed. D. H. Peterson). Geophys. Monogr. A Geophys. Union 55, 141-50.

Mellack J. M. \& Kilham P. (1974) Photosynthetic rates of phytoplankton in East African Soda Lakes. Oecologia 33, 220-6.
Milbrink G. (1977) On the limnology of two alkaline lakes (Nakuru and Naivasha) in the East Rift Valley systems in Kenya. Int. Rev. Geo. Hydrobiol. 62, 1-17.

Morgan J. (2009) Kenya's heart stops pumping. Available from URL: http://news.bbc.co.uk/2/hi/8057316.stm. Accessed 29 April 2009.

Ndetei R. \& Muhandiki V. S. (2005) Mortalities of lesser flamingos in Kenyan rift Valley saline lakes and the implications for sustainable management of lakes. Lake Reserv. Manage. 10, 51-8.

Odada E., Raini J. \& Ndetei R. (2007) Lake Nakuru brief: Experiences and lessons learned brief for Lake Nakuru. Available from URL: http://www.worldlakes.org/ uploads/Nakuru_4.7.04.pdf. Accessed 29 April 2008.

Okoth E. O., Muchiri M., Shivoga W. A., Miller S. N., Rasowo J. \& Ngugi C. C. (2009) Spatial and seasonal variations in phytoplankton community structure in alkaline-saline Lake Nakuru, Kenya. Lake Reserv. Manage. 14, 57-69.

Patoine A., Pinel-Alloul B., Méthot G. \& Leblanc M.-J. (2006) Correspondence among methods of zooplankton biomass measurement in lakes: Effect of community composition on optical plankton counter and sizefractionated seston data. J. Plankton Res. 28, 695-705.

Pinelalloul B. (1995) Spatial heterogeneity as a multiscale characteristics of zooplankton community. Hydrobiologia 300, 17-42.

Raini J. A. (2009) Impact of land use changes on water resources and biodiversity of Lake Nakuru catchment basin, Kenya. Afr. J. Ecol. 47, 39-45.

Ribera d'Alcalà M., Conversano F., Corato F. et al. (2004) Seasonal patterns in plankton communities in a plurriannual time series at a coastal Mediterranean site (Gulf of Napoles), an attempt to discern recurrences and trends. Sci. Mar. 68, 65-83.

Romare P., Daniel E. S., Mark D. S., Jenifer M. S., Arni H. L. \& Judith H. S. (2005) Variation in spatial and temporal gradient in zooplankton spring development, The effect of climatic factors. Freshw. Biol. 50, 100721.

Sameoto D. D. (1986) Influence of the biological and physical environment on the vertical distribution of mesozooplankton and micronekton in the eastern tropical Pacific. Mar. Biol. 93, 263-79.

Schneider G., Lenz J. \& Rolke M. (1994) Zooplankton stock and community structure within the epipelagic zone: A comparison between the central Red Sea and the Gulf of Aden. Mar. Biol. 119, 191-8.

Shivoga W. A., Muchiri M., Kibichi S. et al. (2007) Influences of land use/cover on water quality in the upper 
and middle reaches of River Njoro, Kenya. Lake Reserv. Manage. 12, 97-105.

Small E. B. \& Lynn D. H. (1985) Phyllum Ciliophora. Doflein. In: An Illustrated Guide to Protozoa (eds J. J. Lee, S. H. Hutner \& E. C. Bovee), pp. 604. Society of Protozoology, Lawrence, Kansas.

SUMAWA (2004) Sustainable Management of Watersheds Programme, The River Njoro, Kenya. Environmental Sciences Department, Egerton University, Njoro, Kenya.

Talling J. F. \& Talling I. B. (1965) The chemical composition of African lake waters. Int. Rev. Hydrobiol. 50, 1-32.

Talling J. F., Wood R. B., Prosser M. V. \& Baxter R. M. (1973) The upper limit of photosynthetic productivity of phytoplankton, Evidence from Ethiopian soda lakes. Freshw. Biol. 2, 53-76.

Vanni M. J. (1999) Freshwater zooplankton community structure. Introduction of large invertebrates predators and large herbivorous to a small species community. Can. J. Fish. Aquat. Sci. 45, 1758-70.
Vareschi E. (1978) The ecology of Lake Nakuru (Kenya). 1. Cell density and feeding of the lesser flamingo. Oecologia 32, 11-35.

Vareschi E. (1982) The ecology of Lake Nakuru (Kenya). III. Abiotic factors and primary production. Oecologia 55, 81-101.

Vareschi E. \& Jacobs J. (1985) The ecology of Lake Nakuru (Kenya). VI. Synopsis of production and energy flow. Oecologia 65, 412-24.

Vera L. D., Huszar M. \& Nina F. C. (1998) The relationship between phytoplankton composition and physicochemical variables, a comparison of taxonomic and morphological-functional descriptors in six temperate lakes. Freshw. Biol. 40, 679-96.

Wetzel R. G. (1983) Limnology. pp. 767. CBS College Publishing, New York.

Yasindi A. W. (1995) The Ecology of Ciliated Protozoa in an Alkalin-saline Lake, Lake Nakuru, Kenya. pp. 141. MSc Thesis, University of Guelph, ON, Canada. 